\title{
The effect of the protein value of the diet on the neurological manifestations produced in rats by $\beta, \beta$-iminodipropionitrile
}

\author{
By SABRY RIAD MORCOS* \\ Human Nutrition Research Unit, National Institute for Medical Research, \\ Mill Hill, London, $\mathrm{NW}_{7}$
}

(Received 10 March 1966-Accepted 8 November 1966)

\begin{abstract}
I. 'The 'landing' and 'swimming' tests have been used to detect the onset of the neurological manifestations of toxicity of $\beta, \beta$-iminodipropionitrile (IDPN) in rats.

2. Rats on diets of net percentage of dietary protein calories (NDpCal\%) of $10.1,6.2$ or 4.6 developed the syndrome later than those on diets of lower protein value.

3. L-Thyroxine did not prevent the development of the ECC-syndrome, but only delayed the onset of the action of IDPN.
\end{abstract}

Delay, Pichot, Thuillier \& Marquiset (1952) showed that mice injected with $\beta, \beta$ iminodipropionitrile (IDPN) developed a permanent derangement of motor activity. The animals were hyperactive and tended to run in circles. Similar observations were reported by Thuillier, Burger \& Mouille (1953). Azima \& Grad (1956) found that as little as $4 \mathrm{mg}$ IDPN $/ \mathrm{kg}$ body-weight injected daily into mice produced a state of excitation and agitation which persisted for at least 18 months after administration of IDPN had been discontinued. Histological changes in the nervous system of IDPNintoxicated rats have also been reported. Bachhuber, Lalich, Angevine, Schilling \& Strong (1955) described hydropic degeneration and necrosis of the anterior horn cells of the spinal cord and of the Purkinje cells of the cerebellum. These observations were confirmed by Hartmann \& Stich (1957), who showed that in animals given IDPN there were degenerative changes in the neurons of the central nervous system. The anterior motor horn cells, particularly those of the ventrolateral group, showed severe degenerative changes.

Selye (1957a) described the nervous derangement in rats given IDPN as 'excitation with choreiform and circling movements'-the ECC-syndrome. He found that, for albino rats weighing $100 \mathrm{~g}$, either a daily injection of $20 \mathrm{mg}$ or a single dose of I00 $\mathrm{mg}$ IDPN led, within $3^{-7}$ days, to a fully developed ECC-syndrome. Keratitis with degenerative changes and detachment of the retina were also found with great regularity (Selye, I957 $b$ ). The changes were prevented by giving L-thyroxine (100 $\mu \mathrm{g} /$ rat daily) for about 4 weeks, even when the amount of IDPN administered was increased to a total of $600 \mathrm{mg}$ in 20 days (Selye, 1958).

Sacra \& McColl (1959) showed that the neurotoxic effects developed in $3^{-6}$ days when IDPN $(0.26 \mathrm{mg} / \mathrm{g}$ body-weight) was injected subcutaneously and that the effects produced by a single dose of IDPN ( $1 \cdot 3 \mathrm{~g} / \mathrm{kg}$ body-weight administered orally to rats on a normal diet) were significantly delayed, but not prevented, by pyrixodine,

* Present address: Food Science Research Department, National Research Centre, Dokki, Cairo, UAR (Egypt). 
injected subcutaneously either before or after intoxication. Riboflavine given intravenously caused a temporary improvement in the animals, but had no other effect on the neurotoxic symptoms.

All these investigations were conducted on animals maintained on stock diets and, in view of the results obtained by Morcos \& Platt (1962), it appeared worth while to examine the effect of diets of different protein value on the development of the motor derangement brought about by IDPN.

\section{EXPERIMENTAL}

\section{Animals and diets}

Male hooded rats ranging from 90 to $100 \mathrm{~g}$ in weight were used for the tests. They were housed two in a cage. All were maintained for a preparatory period of I week on Amvilac no. 2 (Glaxo Research Ltd), which has a high protein value (net percentage of dietary protein calories $(\mathrm{NDpCal} \%)=\mathrm{I} 2$ ); to each $\mathrm{kg}$ of it were added $2 \mathrm{~g}$ riboflavine and $0.2 \mathrm{~g}$ pyridoxine. Seventy-two rats were divided into three groups, $a, b$ and $c$; each group was subdivided into six lots of four rats, and each of these lots was fed on one of six experimental diets which had protein values of $\mathrm{NDpCal} \%=10 \cdot 1,6 \cdot 2$, $4 \cdot 6,3 \cdot 7,2 \cdot 1$ or o respectively. The composition of the diets is given in Table $\mathrm{I}$. The diets were supplemented with an additional $2 \mathrm{~g}$ riboflavine and $0.2 \mathrm{~g}$ pyridoxine per $\mathrm{kg}$.

Animals in group $a$ received a daily subcutaneous injection of $0 \cdot 2 \mathrm{mg}$ IDPN/g body-weight during the 2 nd and 3 rd weeks of the experiment. Those in group $b$ had similar treatment with IDPN during the 2 nd and 3 rd weeks and in addition had a daily subcutaneous injection of L-thyroxine ( $\mathrm{r} \mu \mathrm{g} / \mathrm{g}$ body-weight as the sodium salt) during the rst, and and $3^{\text {rd }}$ weeks of the experiment. Those of group $c$ were given experimental diets without toxin or thyroxine.

\section{Procedure}

Food intakes were determined twice a week (one 3-day and one 4-day period). Each day the weights and general appearance of the animals, together with their behaviour in 'landing' and 'swimming' tests (Azima \& Grad, 1956; Selye, 1957a), were recorded.

The landing test. If a normal rat is held by the tail and gradually lowered towards a flat surface (e.g. a table or bench), the animal bends its neck and head dorsally, and extends the fore limbs before landing. Animals exhibiting the ECC-syndrome bend the neck and head ventrally and therefore land on the calvarium. The latter response is reported in this paper as a positive landing test.

The swimming test. Normal rats swim with well co-ordinated movements towards the side of a bath of water and try to escape by climbing out of the water. Rats in which the ECC-syndrome has been established circle violently, churning up the water without any attempt to reach the side or even to keep their heads above the surface; this response is reported as a positive swimming test. 
Table 1. Composition of diets $(\mathrm{g} / \mathrm{kg})$

\begin{tabular}{lrrrrrr} 
& \multicolumn{7}{c}{ Diet with protein value (NDpCal\%) of } \\
\cline { 2 - 7 } \multicolumn{1}{c}{ Ingredient } & $10 \cdot 1$ & $6 \cdot 2$ & $4 \cdot 6$ & 3.7 & $2 \cdot 1$ & 0 \\
Hydrogenated vegetable oil & 100 & 100 & 100 & 100 & 100 & 100 \\
Arachis oil & 50 & 50 & 50 & 50 & 50 & 50 \\
Fat-soluble vitamin mixture* & & & & & & \\
B-vitamin mixturet & 10 & 10 & 10 & 10 & 10 & 10 \\
Salt mixturef & 40 & 40 & 40 & 40 & 40 & 40 \\
Casein & 170 & 10 & 15 & 12 & 6.75 & 0 \\
Dry beef powder & 30 & 30 & 0 & 0 & 0 & 0 \\
Milled bread-crumbs & 600 & 600 & 600 & 480 & 270 & 0 \\
Glucose & 0 & 0 & 0 & 30 & 82.5 & 150 \\
Maize starch & 0 & 160 & 185 & 258 & 386 & 550 \\
Potato starch & 0 & 0 & 0 & 20 & 55 & 100
\end{tabular}

* Vitamin A 400000 i.u., vitamin D 200000 i.u., vitamin $\mathrm{K} 40 \mathrm{mg}$, and $2 \mathrm{ml}$ of $34 \%$ (w/v) tocopherol (vitamin $\mathrm{E}$ ), in $\mathrm{I} 00 \mathrm{ml}$ arachis oil. Each rat was given $0.1 \mathrm{ml}$ of the oil once every week.

† Thiamine hydrochloride $0.3 \mathrm{~g}$, riboflavine $\mathrm{I} \cdot 0 \mathrm{~g}$, pyridoxine hydrochloride $0.2 \mathrm{~g}$, calcium pantothenate $6.0 \mathrm{~g}$, nicotinic acid $20.0 \mathrm{~g}$, inositol $20.0 \mathrm{~g}, p$-aminobenzoic acid $60.0 \mathrm{~g}$, biotin $0.2 \mathrm{~g}$, folic acid $0.2 \mathrm{~g}$, cyanocobalamin $0.005 \mathrm{~g}$ and choline chloride $60.0 \mathrm{~g}$; made up to I $\mathrm{kg}$ with maize starch (Miller \& Bender, I955).

† $\mathrm{Ca}_{3}\left(\mathrm{PO}_{4}\right)_{2} 600 \mathrm{~g}, \mathrm{NaCl}_{250} \mathrm{~g}, \mathrm{KCl}{ }_{15} \mathrm{~g},{ }_{3} \mathrm{MgCO}_{3} \cdot \mathrm{Mg}(\mathrm{OH})_{2} \cdot{ }_{3} \mathrm{H}_{2} \mathrm{O} 65 \mathrm{~g}$, ferrous citrate $25 \mathrm{~g}$, $\mathrm{MnCl}_{2} \cdot \mathrm{H}_{2} \mathrm{O} 7 \mathrm{~g}, \mathrm{CuCO}_{3}(\mathrm{CuOH})_{2} 2 \mathrm{~g}, \mathrm{ZnC} \mathrm{O}_{3}$ I gand $\mathrm{NaF}$ o. I g (D. S. Miller \& P. R. Payne, I 963 , personal communication).

\section{RESULTS}

All the animals given IDPN lost weight. Of those not given the toxin, the rats on diets of low protein value ( $\mathrm{NDpCal} \%=3 \cdot 7,2 \cdot 1$ or o) lost weight, but the losses were less than those of animals on the corresponding diets with toxin (Fig. I $B$ ). L-Thyroxine reduced the weight loss in some of the animals given diets containing toxin, but the effect was not consistent.

\section{Rats given IDPN only}

The onset of the ECC-syndrome in the animals on the diets of different protein value is shown in Table 2. All the animals given the diet with a protein value of $\mathrm{NDpCal} \%=0$ were intoxicated by the 6 th day, at a time when all the animals on the high-protein diet still appeared to be normal. By the gth day, however, all the animals were affected and it became obvious that, although increasing the protein value of the diet delayed the onset of the signs, it did not prevent them.

Table 2. Number of rats, out of four, showing ECC-syndrome (Selye, 1957 a) at different days after administration of $\beta, \beta$-iminodipropionitrile with and without $\mathrm{L}$-thyroxine

\begin{tabular}{|c|c|c|c|c|c|c|c|c|c|c|c|c|c|c|c|}
\hline \multirow{2}{*}{$\begin{array}{c}\text { Protein } \\
\text { value } \\
\text { of diet } \\
\text { (NDpCal } \% \text { ) }\end{array}$} & \multicolumn{6}{|c|}{$\begin{array}{l}\text { Rats given IDPN } \\
\text { only for (days): }\end{array}$} & \multicolumn{9}{|c|}{$\begin{array}{l}\text { Rats given IDPN + thyroxine } \\
\text { for (days): }\end{array}$} \\
\hline & 5 & 6 & 7 & 8 & 9 & 10 & 5 & 6 & 7 & 8 & 9 & I0: & I I I & 121 & 1314 \\
\hline 10.1 & 0 & 0 & I & 3 & 4 & 4 & 0 & 0 & 0 & 0 & $\mathbf{I}$ & 2 & 2 & 3 & \\
\hline $6 \cdot 2$ & 0 & I & 3 & 4 & 4 & 4 & 0 & 0 & 0 & 0 & 2 & 3 & & 3 & $3^{*} 3^{*}$ \\
\hline $4^{\cdot 6}$ & 0 & $I$ & 4 & 4 & 4 & 4 & 0 & I & I & 2 & 3 & 4 & 4 & 4 & 44 \\
\hline $3 \cdot 7$ & 0 & 3 & 4 & 4 & 4 & 4 & 0 & I & 2 & 4 & 4 & 4 & 4 & 4 & $43 *$ \\
\hline $2 \cdot 1$ & 0 & 3 & 4 & 4 & 4 & 4 & 0 & 3 & 4 & $3^{*}$ & $3^{*}$ & $3^{*}$ & $3^{*}$ & $3^{*}$ & $3^{*} 3^{*}$ \\
\hline 0 & 0 & 4 & 4 & 4 & 4 & 4 & 0 & 3 & I* & . & . & . & . & . & - \\
\hline
\end{tabular}




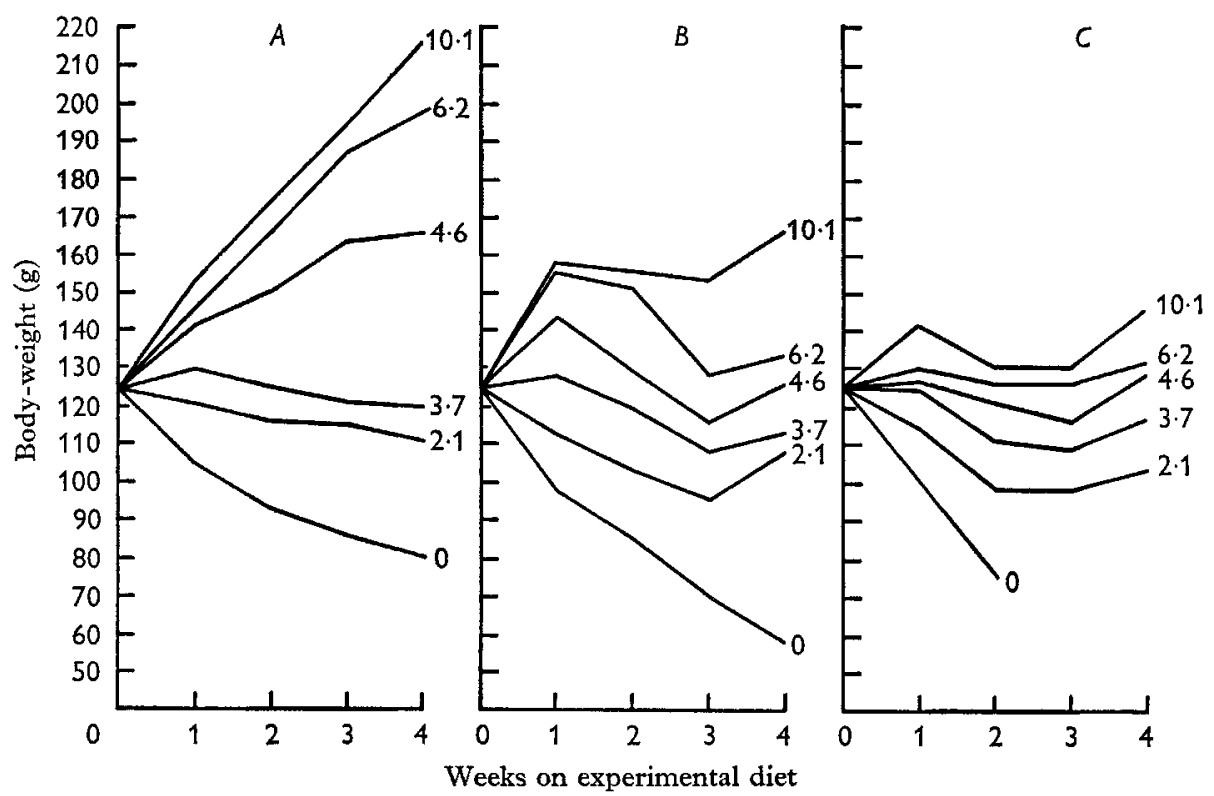

Fig. I. Weight curves of rats maintained on diets of different protein value (NDpCal\%), shown on the curves, alone or with $\beta, \beta$-iminodipropionitrile or $\mathrm{L}$-thyroxine or both, in successive weeks of the experiment: $A$, controls; $B$, animals on diet alone for Ist week, diet + IDPN for 2nd and 3 rd weeks, diet without IDPN for 4 th week; $C$, animals on diet $+\mathrm{L}$-thyroxine for rst week, diet +L-thyroxine + IDPN for and and 3 rd weeks, diet + L-thyroxine only for $4^{\text {th }}$ week.

Table 3. Number of rats, out of four, on various diets, showing ECC-syndrome (Selye 1957a) at different periods after administration of $\beta, \beta$-iminodipropionitrile

\begin{tabular}{|c|c|c|c|c|c|c|c|c|c|c|c|}
\hline \multirow{2}{*}{$\begin{array}{c}\text { Protein } \\
\text { value of } \\
\text { diet } \\
(\mathrm{NDpCal} \%)\end{array}$} & \multirow{2}{*}{$\begin{array}{c}\text { Intake of } \\
\text { utilizable } \\
\text { protein in } \\
\text { 2-week } \\
\text { period* } \\
\text { (kcal) }\end{array}$} & \multicolumn{10}{|c|}{ Rats given IDPN for (days): } \\
\hline & & 5 & 6 & 7 & 8 & 9 & 10 & II & 12 & I3 & I4 \\
\hline IO. I T & 68 & 0 & 0 & 0 & 0 & $\mathbf{I}$ & . & & . & 4 & . \\
\hline $10 \cdot 1$ & 55 & 0 & $\circ$ & I & . & 4 & . & . & . & . & . \\
\hline $6.2 \mathrm{~T}$ & 44 & 0 & 0 & $\circ$ & ○ & 2 & . & . & . & $3 \dagger$ & . \\
\hline $6 \cdot 2$ & 35 & 0 & I & . & 4 & - & - & . & - & $\cdot$ & . \\
\hline $4.6 \mathrm{~T}$ & 33 & 0 & I & . & . & . & 4 & . & . & . & \\
\hline $37 \mathrm{~T}$ & $2 \mathrm{I}$ & 0 & $\mathbf{I}$ & . & 4 & . & & . & . & . & . \\
\hline $4 \cdot 6$ & r9 & 0 & $\mathbf{I}$ & 4 & & . & . & . & . & . & . \\
\hline 377 & 15 & o & 3 & 4 & . & . & . & . & . & . & . \\
\hline 2.x $T$ & 10 & 0 & 3 & 4 & . & . & . & . & . & . & \\
\hline $2 \cdot I$ & 6 & 0 & 3 & 4 & . & . & . & . & . & . & \\
\hline
\end{tabular}

$T$, animals in group $b$, having thyroxine.

* NDpCal $\% \times$ intake of food $\times \mathrm{kcal} / \mathrm{g}$ food.

$\uparrow$ Number of survivors. 


\section{Rats given IDPN+L-thyroxine}

Table 2 shows the results of tests on rats given toxin and L-thyroxine. Again, the effect of increasing the protein value of the diet was to delay and not to prevent the development of the syndrome. As in rats given thyroxine, those on the diets with the lowest protein values were more markedly affected by the 6 th day. No changes were seen in the animals on the diets of $\mathrm{NDpCal}_{\%}=\mathrm{r} 0 . \mathrm{I}$ or 6.2 until the 9 th day, and then only one or two of the four in the subgroup were affected.

The animals receiving IDPN and thyroxine ate more food than those receiving IDPN without thyroxine, and the difference in food intake may have accounted in part for the apparent effect of thyroxine. From the findings set out in Table 3 , it will be seen that, as the intake of utilizable protein was increased in the 2-week period, there was a tendency for the ECC-syndrome to be established later in all the animals. Further, it will be seen that for diets of $\mathrm{NDpCal} \%=\mathrm{I} 0 \cdot \mathrm{I}, 6.2$ and 4.6 the time of the onset of the syndrome in the animals to which thyroxine had been administered throughout the experimental period was appreciably delayed.

\section{DISCUSSION}

Sacra \& McColl (I959) found that neurotoxic effects appearing in animals treated with IDPN occurred in 3-6 days. The onset was delayed until the $5^{\text {th }}$ or 6 th day if pyridoxine was administered. The diets used in the experiment now presented contained pyridoxine and the syndrome was found to develop between the 6th and 8th days, thus confirming the observations of Sacra \& McColl.

The inhibitory effect of L-thyroxine reported by Selye (1958) has not been confirmed. One or more of the rats maintained on diets of $\mathrm{NDpCal} \%=10.1$ and 6.2 given IDPN + L-thyroxine first gave a positive result in the swimming test on the 9th day, i.e. 2 or 3 days later than animals not given thyroxine. The total amount of L-thyroxine administered to each animal daily was not less than the dose reported by Selye to be completely inhibitory. Selye terminated his experiment on the 2oth day, 3 days after the manifestation of the syndrome in the group given IDPN alone. If he had continued the experiment longer, he might have found that thyroxine had only a delaying action and not a preventive effect.

All the findings on the occurrence of the ECC-syndrome reported hitherto were with rats on a stock diet. In the work described here the effects of the protein value of the diet on the neurological manifestations produced by IDPN were studied.

Platt (1958, I961) drew attention to clinical evidence that protein-calorie deficiency affects the central nervous system in man. Platt \& Stewart (1960) and Meyer, Stewart \& Platt (r96r) showed that the nissl substance in the nerve cells of the spinal cord of malnourished pigs was altered and that there was a relationship between the chromatolysis of the anterior horn cells in the spinal cord and the severity of the protein-calorie deficiency. On the basis of these observations it seems possible that dietary protein deficiency makes the central nervous system more vulnerable to the toxic effect of IDPN. 
The author wishes to express his gratitude to Professor B. S. Platt, Director of the Human Nutrition Research Unit, National Institute for Medical Research, for suggesting the work and for his constant advice. He is indebted to Abbott Laboratories $\operatorname{Ltd}$ for the supply of $\beta, \beta$-iminodipropionitrile.

\section{REFERENCES}

Azima, H. \& Grad, B. (1956). Fedn Proc. Fedn Am. Socs exp. Biol. r5, 6.

Bachhuber, T. E., Lalich, J. J., Angevine, D. M., Schilling, E. D. \& Strong, F. M. (1955). Proc. Soc. exp. Biol. Med, 89, 294 .

Delay, J., Pichot, P., Thuillier, J. \& Marquiset, J. P. (1952). C.r. Séanc. Soc. Biol. r46, 533.

Hartmann, H. A. \& Stich, H. F. (1957). Science, N. Y. 125, 445.

Meyer, A., Stewart, R. J. C. \& Platt, B. S. (I96r). Proc. Nutr. Soc. 20, xviii.

Miller, D. S. \& Bender, A. E. (1955). Br. F. Nutr. 9, 382.

Morcos, S. R. \& Platt, B. S. (I962). Proc. Nutr. Soc. 21, xxxi.

Platt, B. S. (1958). In Proc. int. Congr. trop. Med. Malar. vi. Lisbon, p. 219.

Platt, B. S. (196r). In Chemical Pathology of the Nervous System, p. I I4. [J. Folch-Pi, editor.] London: Pergamon Press.

Platt, B. S. \& Stewart, R. J. C. (1960). Proc. Nutr. Soc. 19, viii.

Sacra, P. \& McColl, J. D. (1959). Archs int. Pharmacodyn. Ther. 122, 94.

Selye, H. (1957a). Revue can. Biol. 16, I.

Selye, H. (1957b). Am. F. Opthal. 44, 763.

Selye, H. (1958). F. clin. exp. Psychopath. 19, 97.

Thuillier, J., Burger, A. \& Mouille, P. (1953). C. r. Séanc. Soc. Biol. 147, 1052. 